\title{
Desmoplastic small round cell tumor of the abdomen
}

\author{
R. Andrés, J. I. Mayordomo, D. Isla, S. Ramón y Cajal ${ }^{1}$, E. Tejero² ${ }^{2}$ A. Navarro ${ }^{2}$, E. Polo, R. Lastra, E. Ortega, \\ M. Ruiz-Echarri, R. Lozano ${ }^{2}$, A. Tres
}

\section{Summary}

A 21-year old woman presented with a 2-month history of abdominal pain. The diagnostic work-up disclosed a $17-\mathrm{cm}$ intraperitoneal mass. Biopsy showed islets containing small round cells surrounded by abundant desmoplastic stroma. Immunohistochemistry was strongly positive for desmin and weakly positive for vimentin and neuron-specific enolase. Pathological diagnosis was intraabdominal round cell desmoplastic tumor. The patient underwent an intensive schedule of highdose alkylator-based chemotherapy, the P6 protocol, designed by the Pediatrics Division of the Memorial Sloan-Kettering Cancer Center. She had a partial response and subsequently underwent resection of the residual mass followed by high-dose chemotherapy with stem cell support. Ten months later, the patient had disease progression and is currently receiving second-line chemotherapy.

Key words: Desmoplastic small round cell tumor. High-dose chemotherapy- Intrabdominal tumor.

Oncología, 2006; 29 (2):73-75

\footnotetext{
${ }^{1}$ Division of Medical Oncology. Division of Pathology

${ }^{2}$ Division of Surgery

University Hospital. Zaragoza. Spain
}

Recibido: 12.07 .05

Aceptado: 02.09.05

\section{Resumen}

Una mujer de 21 años consultó por dolor abdominal de dos meses de evolución. El estudio que se le practicó puso de manifiesto la existencia de una masa intraperitoneal de $17 \mathrm{~cm}$. La biopsia demostraba la existencia de islotes de células pequeñas y redondas, rodeadas de abundante estroma desmoplásico. La inmunohistoquímica fue fuertemente positiva para desmina y débilmente positiva para vimentina y enolasa neuronal específica. Con estos hallazgos el diagnóstico anatomopatológico fue de tumor desmoplásico de célula pequeña intraabdominal. La paciente inició tratamiento con un esquema intensivo de altas dosis de quimioterapia basada en agentes alquilantes, de acuerdo con el Servicio de Pediatría del Memorial Sloan-Kettering Cancer Center, denominado protocolo P61. Tras el mismo presentó respuesta parcial siendo sometida a cirugía de las masa residuales y a continuación a quimioterapia de altas dosis con trasplante autólogo de médula ósea. Diez meses después la paciente presentó progresión de la enfermedad por lo que está recibiendo un asegunda línea de quimioterapia.

Palabras clave: Tumor desmoplásico de célula pequeña. Quimioterapia de altas dosis. Tumor intrabdominal. 


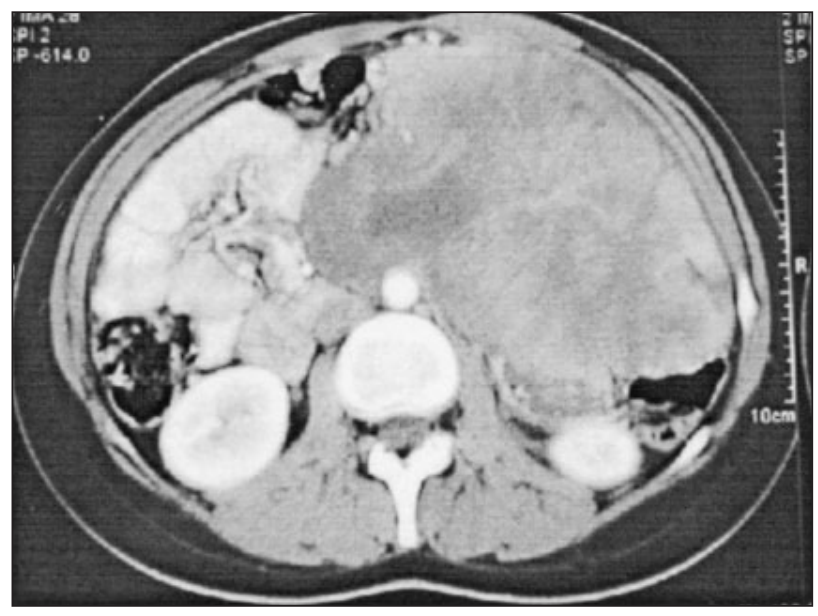

Figure 1. Abdominal scan showing an intraabdominal mass displacing the small bowel.

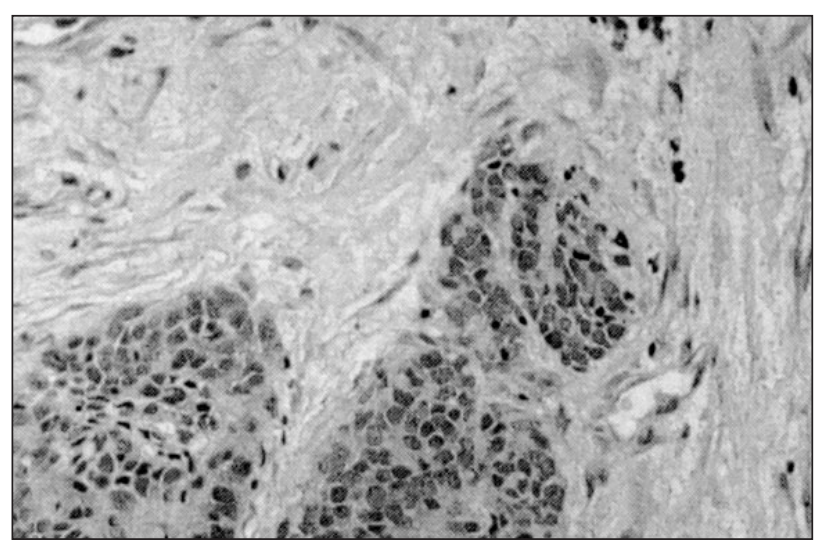

Figure 2. Tumor composed of small round cells surrounded by abundant desmoplastic stroma.

A 21 year-old-female presented with a 2-month history of abdominal fullness. Physical examination revealed a large mass in left hemiabdomen. Blood chemistries and serum markers (CEA, CA 12.5, enolase) were normal. Computed tomography of the body revealed a $17-\mathrm{cm}$ heterogeneus intraabdominal mass and moderate ascites (Figure 1). The patient underwent exploratory laparotomy revealing an intraperitoneal tumor with splenic extension but without an obvious apparent primary site. Biopsy was performed. Microscopically the tumor showed characteristic malignant features. It consisted of islets of small round cells surrounded by abundant desmoplastic stroma (Figure 2). Immunohistochemical stains were strongly positive for desmin (Figure 3) and weakly positive for vimentine (Figure 4) and for neuron-specific enolase (Figure 5). Epithelial membrane antigen, cytokeratin, leucocyte common

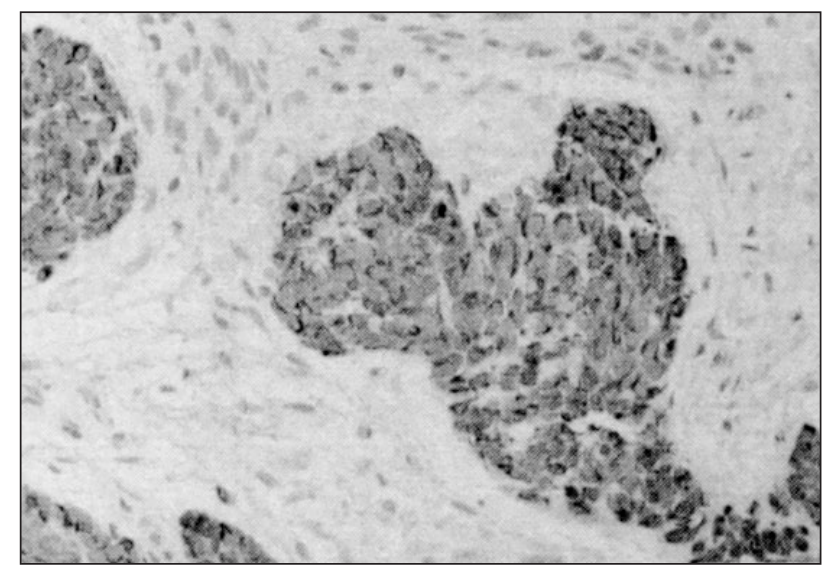

Figure 3. Immunohistochemical stains revealed strong positivity for desmin.

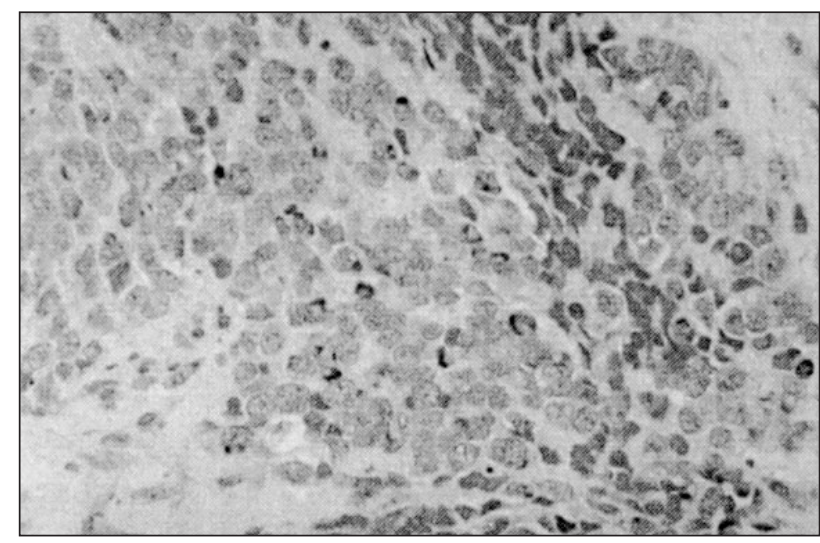

Figure 4. Immunohistochemical stains revealed weak positivity for vimentine.

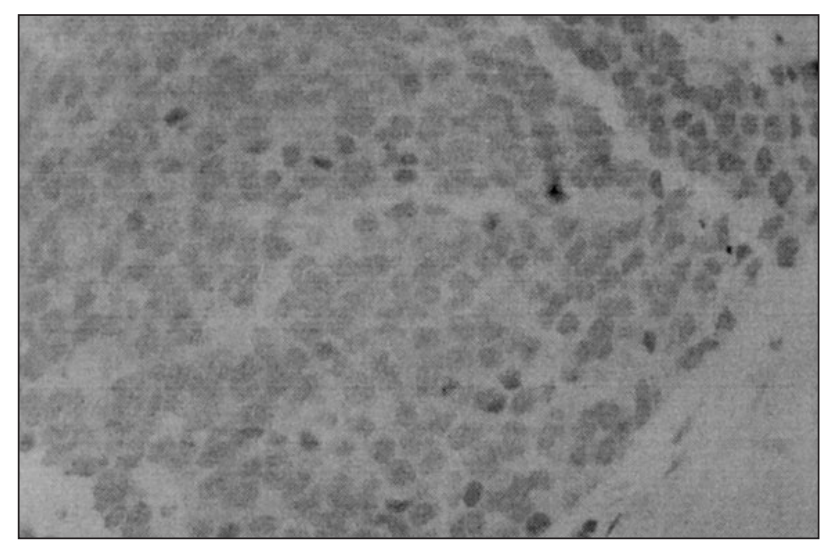

Figure 5. Immunohistochemical showed weak positivity for neuron-specific enolase.

antigen, chromogranin, synaptophysin, S-100 protein and CEA were negative. After diagnosis of desmoplastic small round-cell tumor (DSRCT), treatment consisted of a high-dose alkylator-based regi- 
men, according to the Deparments of Pediatrics, from Memorial Solan-Kettering Cancer Center, labeled the P6 protocol ${ }^{1}$. From August to October 2002, seven cycles were administrated. Courses 1 , 2,3 , and 6 consisted of high-dose cyclophosphamide, doxorubicin and vincristine. Courses 4, 5, and 7 consisted of ifosfamide, etoposide and mesna. The patient received prophylaxis againts pneumocystis carinii pneumonia and granulocyte colony-stimulating factor (G-CSF) was given. Toxicity consisted of grade 4 myelosupression and grade 3 mucositis. After P6 chemotherapy, the patient had a 6-cm residual mass, two nodules in pelvis and a hepatic nodule, which were resected. In order to consolidate disease regression, a myeloablative regimen with stem-cell rescue was performed, wich included high-dose thiotepa $\left(1,2 \mathrm{~g} / \mathrm{m}^{2}\right)$ carboplatin $\left(2 \mathrm{~g} / \mathrm{m}^{2}\right)$ and cyclophosphamide $\left(9,6 \mathrm{~g} / \mathrm{m}^{2}\right)$.

Ten months later, intraabdominal progression was detected and the patient started a second-line of chemotherapy, which goes on at the moment.

Desmoplastic small round-cell tumor is a relatively newly recognized neoplams ${ }^{2}$. It is commonly seen in adolescent boys and predominant or exclusive intraabdominal localization, with inconstant organt involvement. Microscopically findings consist in the presence of discrete islands of compact, small epithelial-like cells encased in a fibrous stroma and immunohistochemical studies indicating a primitive malignant neoplams of uncertain histogenesis capable of simultaneously expressing epithelial, mesenchymal, and, less consistently, neural phenotypes $^{3}$. Prognosis is poor because these tumors are relatively unresponsive to coventional chemotherapy, but a combination of agressive surgical debulking, high-dose chemotherapy and myeloablative chemotherapy with stem cell rescue appears to lead to an improved outcome $e^{1,4,5}$.

\section{References}

1. BH Kushner, MP LaQuaglia, N Wollner, PA Meyers, KL Lindsley, F Ghavimi, TE Merchant, F Boulad, NV Cheung, MA Bonilla, G Grouch, JF Kelleher, PG Steinherz, WL Gerald. Desmoplastic small round-cell tumor. Prolonged progression-free survival with aggressive multimodality therapy. J Clin Oncol 1996; 14 (5): 1526-1531.

2. Gerald WL, Rosai J. Desmoplastic small-cell tumor with divergent differentiation. Pediatr Pathol 1989; 9: 177-183.

3. Gonzalez-Crussi F, Crawford SE, Sun CJ. Intraabdominal desmoplastic small-cell tumors with divergent differentiation - Observations on three cases of childhood. Am J Surg Pathol 1990; 14: 633-642.

4. Kurre P, Felgenhauer JL, Miser JS, Patterson K, Hawkins DS. Successful dose-intensive treatment of desmoplastic small round cell tumor in three children. J Pediatr Hematol Oncol 2000; 22(5):446-450.

5. Marina NM, Pappo AS, Parham MD, et al: Chemotherapy dose-intensification for pediatric patients with Ewing's family of tumors and desmoplastic small round-cell tumors: A feasibility study at St. Jude Children's Research Hospital. J Clin Oncol 17:180-190, 1999.
Correspondence:
Dra. R. Andrés
Servicio de Oncología Médica
Hospital Clínico Universitario
Av. San Juan Bosco, 15
E-50009 Zaragoza
E-mail: andresraquel@ @otmail.com 